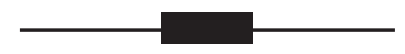

\title{
Introduction
}

\section{The Personal and the Political}

The central task of our journal is to present outstanding work on religion. Through our focus on individual scholars in the Portrait section, we are also able to consider how such work is produced, and our hope is to reveal the intellectual, institutional, political, and personal factors behind research that has helped us to revive and reconstruct our field. The subject of this year's Portrait, Talal Asad, has famously addressed questions about the category of religion in unusually productive and provocative ways. ${ }^{1}$ Published here for the first time, Asad's autobiographical observations take the reader through some of the key relationships and events of his life, from a remarkable childhood during which he witnessed the violence of Partition first-hand, to what happened in 1950 when he arrived in London from Pakistan and began to discern the problems behind "the local version of modern civilization into which [he] was being unevenly assimilated," to the process of becoming an anthropologist and an ethnographer.

Asad's account shows him in dialogue with Marx and Wittgenstein, but also with his parents: his mother's prayers, fasts, and recitations proved to be central factors in prompting him to articulate his own ideas on religion. Yet even as he writes illuminatingly about the development of personal viewpoints, he remains mindful of the historical and ideological conditions through which notions of 'belief' have reinforced liberal distinctions between the nation-state and the morally autonomous individual, and whereby religion has come to be seen as opposed to both politics and the secular. The commentaries on Asad's work by his colleagues reveal the wide-ranging resonance of his ideas. Contributors show us how Asad's writings have questioned the validity of transhistorical views of religion, revealed the power dynamics behind practices of translation, anatomized secular forms of critique, and had an impact on the reformation of both Buddhist and Religious Studies. The warmth and engagement of these pieces are striking: in many cases they are not only about ideas but also about friendships.

A well-known strand in Asad's work has explored the entangled genealogies of Christianity and Islam. Further juxtapositions of these two religions occur elsewhere in this volume. Our special section, titled "Elsewhere Affects," contains ethnographic essays on Protestant and Muslim approaches to themes that, in Butticci and Mittermaier's words, "might not be graspable by vision or even reason." Even as they explore questions of imagination and aesthetics, however, contributors discuss the political engagements involved by Elsewheres that traverse the spatiotemporal realms of engagement between human and divine spheres of activity.

A second theme that suffuses various sections of this volume is precisely temporality. Asad discusses both genealogy and his own past, but he concludes by reflecting on COVID-19 and advocating for a critical anthropology that can grasp "the global temporalities of our crisisridden world." The three essays that make up our Debate section contain vivid and immediate anthropological reflections on the crises precipitated by COVID-19. Contributors trace the varied impacts of the pandemic through the lenses of 'the black church' in America, rhetorics 
of truth and anti-globalism in Turkey, and Korean-Christian diasporas, but each also addresses broader questions of the politics of knowledge. Directly or indirectly, these pieces ask what kinds of information and expertise seem most attractive during a time of emergency, including what kinds of ethnographic insight can contribute most effectively to such situations. Temporality and critique are also harnessed together in distinctly urgent, performative ways in Kyle Byron's article, which is an exploration of "rhythms of war" as manifested in American evangelical street preaching, and they come together again - in a very different way-through Amy Binning's exploration of Tibetan Buddhist "prophecies of decline."

Finally, we point to a further theme that surfaces at various points in the volume-apparently serendipitously but also, surely, as a sign of our times. Heather Mellquist Lehto's discussion of "infrastructuring in the meantime" reflects on how her Christian interlocutors hope to "capacitate a more livable future, building a bridge to nowhere-yet." The politics of such infrastructural imaginaries are clear, and they point to signs of hope that anthropologists as well as 'believers' are searching for. Byron's essay is also full of references to the ways in which preachers attempt ambitiously to reimagine urban infrastructure as religious infrastructure, just as Binning shows us how a Californian Buddhist community similarly refers to the power of imagining futures in both metaphorical and material ways. However, it is precisely against an item of infrastructure-the Dakota Access Pipeline-that the Lakota communities described by Ryan Goeckner, Sean M. Daley, Jordyn Gunville, and Christine M. Daley are protesting. Furthermore, although the media may not have noticed, such protest is formed out of spiritual practices, acting not only in the name of tradition, but also in light of the future.

Much of this volume takes up themes directly addressed by, or related to, an Asadianinspired anthropology. Here we also publish an important piece about, and partially by, a very different anthropologist who discussed Christianity and the secular before 'anthropologies' of either of these fields existed, and who-in her own way-was concerned to think through the relationships between religion, the body, and scripture. In 2005, toward the end of her life, Mary Douglas wrote a Preface to the Hebrew translation of Purity and Danger, and we republish that Preface here, alongside Albert I. Baumgarten's astute reflections on the personal and intellectual context of Douglas's writing on the Hebrew Bible. ${ }^{2}$

We cannot conclude this introduction without expressing our heartfelt thanks to our coeditor for many years, Ruy Llera Blanes, who has been a tremendous colleague and without whom the journal would not be the international source for critical thinking on religion that it has become. In addition, we thank Diana Espírito Santo, our meticulous reviews editor, for all the hard work she has performed over the past seven years. Under her careful direction, the reviews section has become an important and well-read part of our journal.

As our Debate section reminds us, living with COVID-19 this year has changed how we see the world and work within it. As we commend this volume to readers, we continue to plan for the future. We welcome our new book reviews editors, Anastasios Panagiotopoulos and Eugenia Roussou, who will take up the reins for the 2021 volume. ${ }^{3}$ Looking ahead, we anticipate that the wonderful scholarship published in Religion and Society will continue to offer a critical lens through which to see the links between personal engagement and political action in multiple manifestations across the globe. 


\section{NOTES}

1. An Arabic version of Asad's essay, translated by Khaled Furani, will be published in 2020 as "Ta'amullat min As-Sirah adh-Dhatiyyah fi ad-Din wal Anthropolojya" in Idafat: Arab Journal of Sociology 49-50: $13-22$.

2. We take the opportunity here to thank Richard Fardon, Douglas's literary executor, for his assistance to Albert Baumgarten in the preparation of the piece.

3. We invite readers to look at the agenda of our incoming reviews editors at https://journals.berghahnbooks.com/_uploads/air-rs/religion-and-society_review_editors_letter.pdf. 